原著

\begin{tabular}{|c|c|c|c|c|c|c|}
\hline \multicolumn{6}{|c|}{ 久留米大学医学部第三内科 } & \\
\hline 藤山 & 増昭॰ & 池田 & 秀夫 & 古田陽一郎 & 松村 & 順 \\
\hline 田辺 & 章弘 & 大林 & 純 & 寺沢 & 足達 & 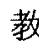 \\
\hline & & 斉藤 & 靖之 & 戸嶋 & & \\
\hline
\end{tabular}

\title{
CLINICAL FEATURES IN FAMILIAL BRADY-ARRHYTHMIA OF ADULT ONSET
}

Masuaki FujiYama, MD, Hideo IKEDA, MD, Yoh-ichiro Furuta, MD, Jun Matsumura, MD, Akihiro Tanabe, MD, Jun Ohbayashi, MD, Masatoshi Terasawa, MD, Kyo AdAChI, MD, Yasuyuki SaIto, MD and Hironori TOSHIMA, MD

The Third Department of Internal Medicine, Kurume University, School of Medicine

\begin{abstract}
概要 成人型家族性徐脈性不整脈（FBA）の4家系について，その心電图所見，臨床症状，血 行動態，心筋組織所見，および臨床経過について検討し以下の結果を得た。1）家系内心電図検 查を施行した55例中徐脈性不整脈は19例(34.9\%)で，これらは脚ブロック．QRS低電位，poor R-wave progression，T波異常，VPCやVTを高頻度に合併した，2）19例中心不全の合併が10 例にみられた。3）FBAの病像完成は30４0才台上推定された。4）心抎大，左室拡張が著明で， その心機能は明らかに低下し，执張型心管症類似例が混在した.5）8例の心筋組織所見として， 肥大，変性，錯綜配列，線維化がみられた，6）未治療例は大部分が突然死し，予後不良であつ たが，pacemaker治療例の経過は比較的良好で，有効な治療といえる．FBAの少なくとも一部 の例は伝導系障害に加光, 固有心筋障害を合併し、特発性心笳症ないしはその類縁疾患々推定 される.FBAの臨床像を特に心筋症との関連の上で㛟討した。
\end{abstract}

家族性不整脈，特に成人に発生する徐脈性不整 脈は比較的まれな疾患群であるが，今日まで十数 家系の報告がなされている1ー8).しかし，その多く は不整脈の概要を家族歴とともに述べるか，遗伝 形式あるいは臨休経過の範囲にとどるかであつ た，一方特発性心筋症のなかに，家系内発生例の 存在する事はEvansのfamilial cardiomegalyの報 告"以来，多くの研究者によつて明らかにされて

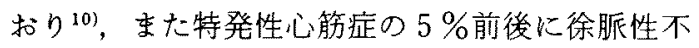
整脈の合併をみると言われる ${ }^{11}$ 家族性不整脈に ついてはその基礎疾患を心筋症とした Griffith ${ }^{5)}$, 有田 ${ }^{6)}$, 外山ら ${ }^{71}$ の報告もあるが, 一般的にはLynch らの報告例のごとく固有心筋組織には異常がな

〔昭和58年 9 月 13 日受稿〕
く，心機能む温存されて子後は比較的良好とする 考光が多(、13)48).

本研究では成人型家族性徐脈性不整脈 (familial brady-arrhythmia以下FBA) を呈した 4 家禾の自験例について，特に心電図所見，臨床 症状, 血行動態, 病理組織所見およびpacemaker 治療, 予後について検討し，併せてこれらFBAと 特発性心筋症との関連性を考察した。

\section{対象および方法}

徐脈性不整脈を有する 4 家系55名の心電図検查 から最低心拍数 $40 /$ 分以下の高度徐脈性不整脈の 19例について，その心電図所見，臨床症状を検討 した。この内の数例につき通常の七ス束心電図， fluid-filled catheterによる各心内圧，Swan-Ganz catheterを用いた心拍出量(熱希釈法), 左室造影, 
冠動脈造影, 右室心内膜心筋生検および以上の観 血的検查前 1 週間内に心ェコー図検查を施行し た.これらFBA群の心機能諸指標を，ほほ正常心 機能と考学られた同様の徐脈性不整脈の対照 群 ${ }^{12} 24$ 例の値と比較検討した。病理組織像につい ては, 心筇肥大, 変性, 錯綜配列, 間質の線維化 の 4 項目について教室のscore分類によつて評価 した ${ }^{13)}$. FBAの臨床経過に関してはpacemaker治 療を施行した10例，未施行 9 例の心不全，死因を 中心に検討した。統計処理はStudent's t test 扰よ び $\chi^{2}$-testを用い $\mathrm{p}<0.05$ (両側検定) を有意とし た.

\section{結 果}

1）家族歴，心電図所見，臨床症状

4 家系中代表的な 2 家系の family treeを図 1 に示寸．両家系之も徐脈性不整脈 (以下BA) の患

family A

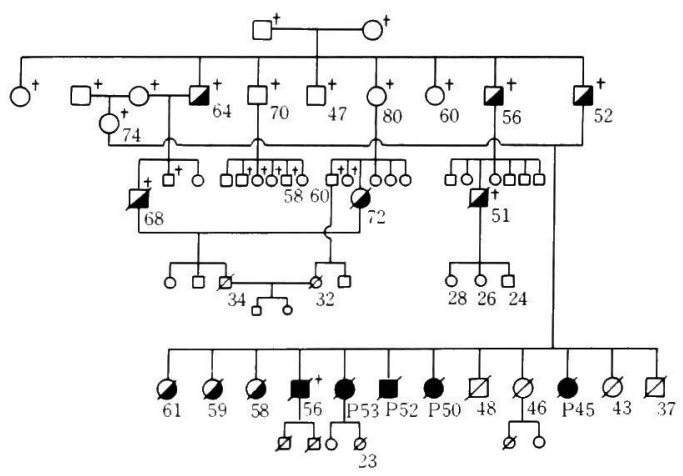

family B

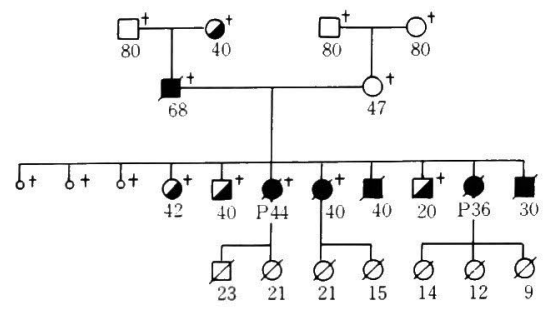

因 1.A家系とB家系のfamily tree

$\square E C G$ examined, $\square$ heart disease, $\square$ AdamsStokes syndrome and/or congestive heart failure due to brady-arrhythmias. $\mathrm{P}$ : pacemaker implantation, + : death

（図中数字は調查時あるいは死亡時年令）
者が多発し（表 1)，A家系には血族婚を認めた。 $\mathrm{A}$ 家系は心電図調査施行の21例中 BA 110 例 (47.6\%)，I 度房室ブロックが 2 例にみられた。 BA10例の内訳は, 持続性心房停止 2 例, 完全房室 ブロック 3 例，徐脈性心房細動ないし粗動 5 例で あつた.図 2 は同家系 2 例の心電図を示している。 これらの例のごとくBA10例に招いて，QRS波の 低電位差を 3 例に, $V_{1}$ から $V_{3}$ ないし $V_{4}$ をでのR波 が久除するか， $0.05 \mathrm{mVW内のいわゆる} \mathrm{poor} \mathrm{R-}$ wave progression（PRP） 9 例 (90\%)，T波の 平低化，二相性， $\mathrm{T}$ 波陰性化等の T波異常を 5 例 （50\%）に認めた。 2 例に心室性期外収縮（VPC） の多発ないし多源性VPC，1 例には左脚前枝ブ ロックを合併していた．Adams-Stokes発作ない 乙脳虚血症状を呈するものは 4 例，心不全のみは 4 例, 両者を合併するもの 2 例であり，10例中 6 例 $(60 \%)$ に心不全をみた。 NYHA分類では10例 とも II 度以上で, III度以上が 4 例であった(表 1 )。

B家系では心電図㭘査施行の13例中 4 例 （30.7\%）にBAを認め, 完全房室ブロック 3 例, 徐脈性心房細動 1 例であつた。 4 例ともPRPを呈

A.M. 51 y/o male

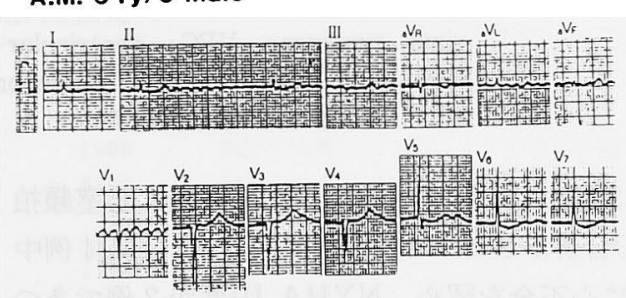

K.M. $56 y / o$ male

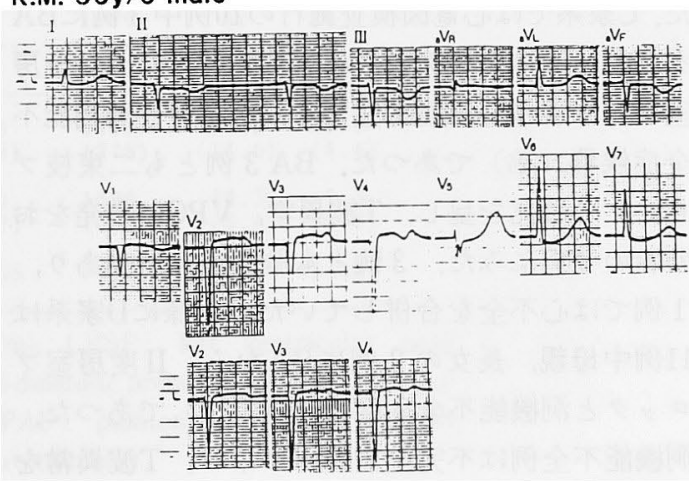

図2、A家系の代表的な 2 症例の心電図 
表 1。家族性徐脈性不整脈19例の臨床，心䉓図所見

\begin{tabular}{|c|c|c|c|c|c|c|c|c|c|}
\hline \multirow{2}{*}{ family } & \multirow{2}{*}{ case } & \multirow[b]{2}{*}{ age } & \multirow{2}{*}{$\operatorname{sex}$} & \multirow{2}{*}{\multicolumn{2}{|c|}{$\frac{\text { symptoms }}{\text { AS ClfF others }}$}} & \multirow{2}{*}{ NYHA } & \multicolumn{3}{|c|}{ ECG abnormality } \\
\hline & & & & & & & arrhyth. & LV PRP & $\mathrm{abn.T}$ \\
\hline \multirow{10}{*}{ A } & R.M. & 53 & $\mathrm{~F}$ & ++ & & III & A.Stand. & + & + \\
\hline & T.K. & 52 & M & & + & II & C-AVB & + & \\
\hline & A.F. & 45 & $\mathrm{~F}$ & + & & II & $C-A V B(a f) \quad V P C$ & + & \\
\hline & K.M. & 56 & M & + & & III & A.Stand. AltB & + & + \\
\hline & A.H. & so & $\mathrm{F}$ & + & & II & C-AVB & + & \\
\hline & $K . N$. & 61 & $\mathrm{~F}$ & + & & II & Bra.-af & + & + \\
\hline & M.H. & 59 & $\mathrm{~F}$ & & + & II & Bra. -af $f A F$ & & \\
\hline & H.M. & 48 & M & + & & N & Bra.-af VPC & + & + \\
\hline & A.M. & 51 & M & + & & IV & Bra. - afEAF & + & \\
\hline & F.M. & 71 & $\mathrm{~F}$ & & + & II & Bra.-af & + & + \\
\hline \multirow{4}{*}{ B } & S.N. & 46 & $\mathrm{~F}$ & + & & III & $\begin{array}{c}C-A V B \text { (af) } \\
\text { RBBB }\end{array}$ & + & \\
\hline & K.M. & 36 & $\mathrm{~F}$ & + & & III & C-AVB RBBB & + & + \\
\hline & C.A. & 40 & $\mathrm{~F}$ & + & & II & $C-A \vee B$ & + & + \\
\hline & K.T. & 68 & M & & + & II & Bra.-af & + & + \\
\hline \multirow{3}{*}{ c } & M.S. & 66 & $\mathrm{~F}$ & + & & II & $\begin{array}{c}\text { Bra, - af VPC } \\
A H B+R B B B\end{array}$ & & \\
\hline & C. A. & 37 & $\mathrm{~F}$ & + & & II & $\begin{array}{l}\text { C-AVB } \\
P H B+R B B B\end{array}$ & & + \\
\hline & K.S. & 35 & M & + & & III & SSS III $\underset{A H B+R B B B}{V P C}$ & $-A V B$ & + \\
\hline \multirow[b]{2}{*}{ D } & Y.T. & 32 & $\mathrm{~F}$ & & + & 11 & SSS II & & + \\
\hline & M.Y. & 62 & $\mathrm{~F}$ & & + & I & Il ${ }^{\circ}-A V B$ & & \\
\hline
\end{tabular}

Abbreviations; AS: Admas-Stokes, CHF : congestive heart failure, NYHA : classification in New York Heart Association, arrhyth.: main arrhytimias, LV: low voltage, PRP : poor $R$ wave progression, abn. $T$ : abnormal $T$ wave, A. Stand.: persistant atrial standstill, C-AVB: complete atrioventricular block, Bar-af\&AF : brady atrial fibrillation and flutter, SSS: sick sinus syndrome, VPC: ventricular premature contraction, AHB: anterior hemi-block, RBBB: right bundle branch block. PHB: posterior hemi-block, VT: ventricular tachycardia

し， 3 例にT波異常があり，VPC多発，心室頻拍 (VT)合併がおのおの 1 例にみられた。 BA 4 例中 3 例に心不全を認め，NYHA III度が 2 例であつ た、C家系では心電図検査施行の10例中 3 例にBA を認め，拈の括の徐脈性心房細動(母親), 完全房 室ブロック(姉), I度房室ブロックを伴ら洞機能不 全症候群（弟）であった。BA 3 例とも二束枝ブ ロックの所見を呈し、T波異常、VPCの多発を括 のおの 2 例にみた。 3 例とも䏚虚血発作があり， 1 例では心不全を合併していた，同様にD家系は 11例中母親，長女の 2 例にBAをみ，II 度房室ブ ロックと洞機能不全症候群（洞停止）であつた。 洞機能不全例は不完全右脚ブロック。T波異常を 認めた。
以上 4 家系の心電国，臨床症状を要約すると以 下のごとくである、心電図調査施行の55例中BA は19例 $(34.5 \%)$ に認められ，I 度房室ブロック が 3 例であつた。 7 例（全体の $12.7 \%$ ，BA中 $36.8 \%)$ に脚ブロック． 4 例 $(7.3 \% ， 21.1 \%)$ に QRSの低電位，13例 $(23.6 \%, 68.4 \%)$ にPRP, 11 例 $(20 \% ， 57.9 \%)$ にT波異常が認められた。ささら に多発ないし多源性 VPC, VT 合併が 6 例 (10.9\%，31.6\%)にみられた。臨床症状として心 不全を伴 うものが10例 $(18.2 \% ， 52.6 \%$ )で，明 らかな脳虚血症状のみを呈した例は 3 例（5.5\%， 15.8\%)であった（表 1).

な拉BA19例の心電図検查時年令は表 1 Kみる ごとく32才から71才，平均50.9才で，14例(BAの 
表 2。心胸比, 左室心ェコ一园所見

\begin{tabular}{|c|c|c|c|c|c|c|c|c|c|}
\hline family & case & age & $\operatorname{sex}$ & $\mathrm{CHF}$ & CTR & LVEDD & ESD & \&S & LVSP/ESD \\
\hline & R.M. & 53 & F & + & 76 & 59 & 44 & 25.4 & 2.91 \\
\hline & T.K. & 52 & M & & 50 & 52 & 37 & 28.8 & 3.32 \\
\hline \multirow[t]{4}{*}{ A } & A.F & 45 & $\mathrm{~F}$ & + & 60.8 & 52 & 36 & 30.8 & 3.33 \\
\hline & H.M. & 48 & M & + & 65 & 54 & 45 & 16.7 & 2.58 \\
\hline & A.M. & 51 & $M$ & + & 63.8 & 51 & 36 & 29.4 & 3.44 \\
\hline & S.N. & 46 & $\mathrm{~F}$ & + & 70.6 & 58 & 46 & 20.7 & 2.39 \\
\hline \multirow[t]{2}{*}{ B } & K.M. & 36 & $\mathrm{~F}$ & + & 61.5 & 49 & 38 & 22.4 & 2.89 \\
\hline & C.A. & 40 & $\mathrm{~F}$ & + & 60.8 & & & & \\
\hline \multirow{2}{*}{ c } & K.S. & 35 & $M$ & + & 58 & 65 & 52 & 20.6 & 2.11 \\
\hline & C.A. & 37 & $\mathrm{~F}$ & & 57 & 50 & 30 & 40.0 & 3.67 \\
\hline \multirow[t]{4}{*}{$\mathrm{D}$} & Y.T. & 32 & $\mathrm{~F}$ & & 54 & 50 & 30 & 40.0 & 4.33 \\
\hline & ilial & $\begin{array}{l}43.2 \\
(7.5)\end{array}$ & & $8 / 11$ & $\begin{array}{l}61.6 \\
(7.3)\end{array}$ & $\begin{array}{l}54.0 \\
(5.1)\end{array}$ & $\begin{array}{l}39.4 \\
(7.2)\end{array}$ & $\begin{array}{l}27.5 \\
(8.0)\end{array}$ & $\begin{array}{l}3.10 \\
(0.66)\end{array}$ \\
\hline & $\begin{array}{l}\text { trols } \\
n=24\end{array}$ & $\begin{array}{c}56.4 \\
(16.4)\end{array}$ & & $5 / 24$ & $\begin{array}{l}53.9 \\
(8.3)\end{array}$ & $\begin{array}{l}49.5 \\
(5.0)\end{array}$ & $\begin{array}{l}32.0 \\
(7.0)\end{array}$ & $\begin{array}{l}35.7 \\
(8.4)\end{array}$ & $\begin{array}{c}4.49 \\
(1.30)\end{array}$ \\
\hline & alues & $<0.02$ & & $<0.05$ & $<0.02$ & $<0.025$ & $<0.01$ & $<0.02$ & $<0.005$ \\
\hline
\end{tabular}

Abbreviations; $\mathrm{CHF}$ : congestive heart failure, CTR: cardiothoracic ratio (\%), LVEDD: left ventricular end-diastolic dimension ( $\mathrm{mm})$, ESD; endsystolic dimension (mm), \%FS: percent fractional shortening (\%), LVSP/ ESD : ratio of left ventricular peak systolic pressure and end-systolic dimension $(\mathrm{mmHg} / \mathrm{mm})$

( ): standard deviation

表 3. 心拍出量, 心内王所見

\begin{tabular}{|c|c|c|c|c|c|c|c|}
\hline family & case & CI & LVSP & EDP & $\mathrm{LV}+\mathrm{dp} / \mathrm{dt}$ & SPAP & mRAP \\
\hline \multirow{3}{*}{ A } & R.M. & 2.14 & 128 & 11 & 1800 & 30 & 7 \\
\hline & T.K. & 2.27 & 123 & 10 & 1500 & 32 & 8 \\
\hline & A.F & 2.19 & 120 & 10 & 1100 & 24 & 6 \\
\hline \multirow{3}{*}{ B } & S.N. & 2.20 & 110 & 17 & 1575 & 50 & 15 \\
\hline & K.M. & 2.48 & 110 & 13 & 1590 & 40 & 9 \\
\hline & C.A. & 2.10 & 135 & 20 & 1667 & 34 & 11 \\
\hline C & K.S. & 1.94 & 110 & 26 & 1000 & 65 & 18 \\
\hline $\mathrm{D}$ & Y.T. & 2.90 & 130 & 11 & 1520 & 28 & 6 \\
\hline \multicolumn{2}{|c|}{ familial } & $\begin{array}{c}2.28 \\
(0.29)\end{array}$ & $\begin{array}{l}120.8 \\
(10.0)\end{array}$ & $\begin{array}{l}14.8 \\
(5.8)\end{array}$ & $\begin{array}{l}1469 \\
(276)\end{array}$ & $\begin{array}{l}37.9 \\
(13.6)\end{array}$ & $\begin{array}{l}10.0 \\
(4.4)\end{array}$ \\
\hline \multicolumn{2}{|c|}{$\begin{array}{r}\text { control } \\
n=21\end{array}$} & $\begin{array}{l}2.52 \\
(0.56)\end{array}$ & $\begin{array}{l}140.4 \\
(30.2)\end{array}$ & $\begin{array}{c}9.0 \\
(2.7)\end{array}$ & $\begin{array}{l}1696 \\
(349)\end{array}$ & $\begin{array}{l}28.3 \\
(5.4)\end{array}$ & $\begin{array}{c}5.3 \\
(1.8)\end{array}$ \\
\hline \multicolumn{2}{|c|}{ p-values } & $>0.1$ & $<0.1$ & $<0.005$ & $>0.1$ & $<0.01$ & $<0.005$ \\
\hline
\end{tabular}

Abbreviations; CI: cardiac index $(1 / \mathrm{m})$, LVSP: left ventricular peak systolic pressure, EDP : left ventricular end-diastolic pressure $(\mathrm{mmHg}), \mathrm{LV}+\mathrm{dp} /$ $\mathrm{dt}$; peak positive $\mathrm{dp} / \mathrm{dt}(\mathrm{mmHg} / \mathrm{sec}$ ), sPAP: pulmonary systolic pressure $(\mathrm{mmHg}), \mathrm{mRAP}$ : mean right atrial pressure $(\mathrm{mmHg})$.

( ): standard deviation. 


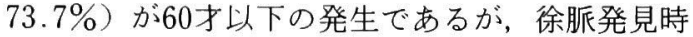
年令を病歴から推定すると平均 46.2 才，18例 (94.7\%) が60才以下. 13例（68.4\%）は50才以下 の発生であつた。一方BA19例の全例とも20才末 満時には明らかな徐脈の指摘がなく, 図 1 に示し たごとく，20才未満例での心電図異常はA家系23 才の I 度房室ブロック例之B家系20才の突然死例 の 2 例のみが推定された。

\section{2）血行動態所見}

表 2 はFBA 11例の臨床所見, 心胸比, 左室工 コ一図所見で,ささらにれら $\mathrm{FBA}$ 群と平均心拍数 に差がなく，心機能が比較的よく保持されている と考えられたBA 24例 ${ }^{22}$ (対照群) とを対比したも のである．FBA群は有意に若年で，心不全の合併 率が高く, 心拡大も強い FBA群の左室拡張末期 径, 収縮末期径は有意に大きく, 左室内径短縮率, 左室収縮期圧 (A 家系の HM, AM例では収縮期血 圧を代用) と左室収縮末期径との比(LVSP/ESD) はいずれも有意に低值であつた。

表 3 は観血的検査を施行したFBA 8 例につい
て，心拍出量，各心内圧所見を表 2 と同様の対照 群21例と対比したものである。心係数, 左室最大 $\mathrm{dp} / \mathrm{dt}$ はFBA群が低值であつたが，両群間に有意 差はなく，左室収縮期圧はFBAで低い傾向を認め た $(\mathrm{p}<0.1)$. 左室拡張末期圧, 肺動脈収縮期圧, 右房平均圧はFBA群で有意の高値を呈した。なお 冠動脈造影を施行した 9 例（1 例は死後造影）に は有意の狭窄病変を認めなかつた。

\section{3) 病理所見}

A家系 3 例 (姉弟例) の右室心筋生検像を図 3 に 示した. case RM, KTでは心筋の肥大，変性，錯 綜配列，間質の線維化がみられるが，その程度は 軽く，一方case AFでは肥大は軽度であつたが, 心筋の变性, 線維化が強く, 特に心筋の錯綜配列 が著明である.FBA 8 症例における心筋組織所見 を表 4 に示す，な扛家系のcase MSは剖検心か らのものを提示した。いずれも病的所見を有し， $\mathrm{A}$ 家系の $\mathrm{AF}, \mathrm{B}$ 家系のSN，C家系のMS例では変 性, 線維化が著明であつた。 AF, SN，D家系のYT には著明な錯綜配列がみられ，KM, MS例では心

\section{Family A \\ T.K. \\ \begin{tabular}{l|l} 
A.F. & R.M.
\end{tabular}}
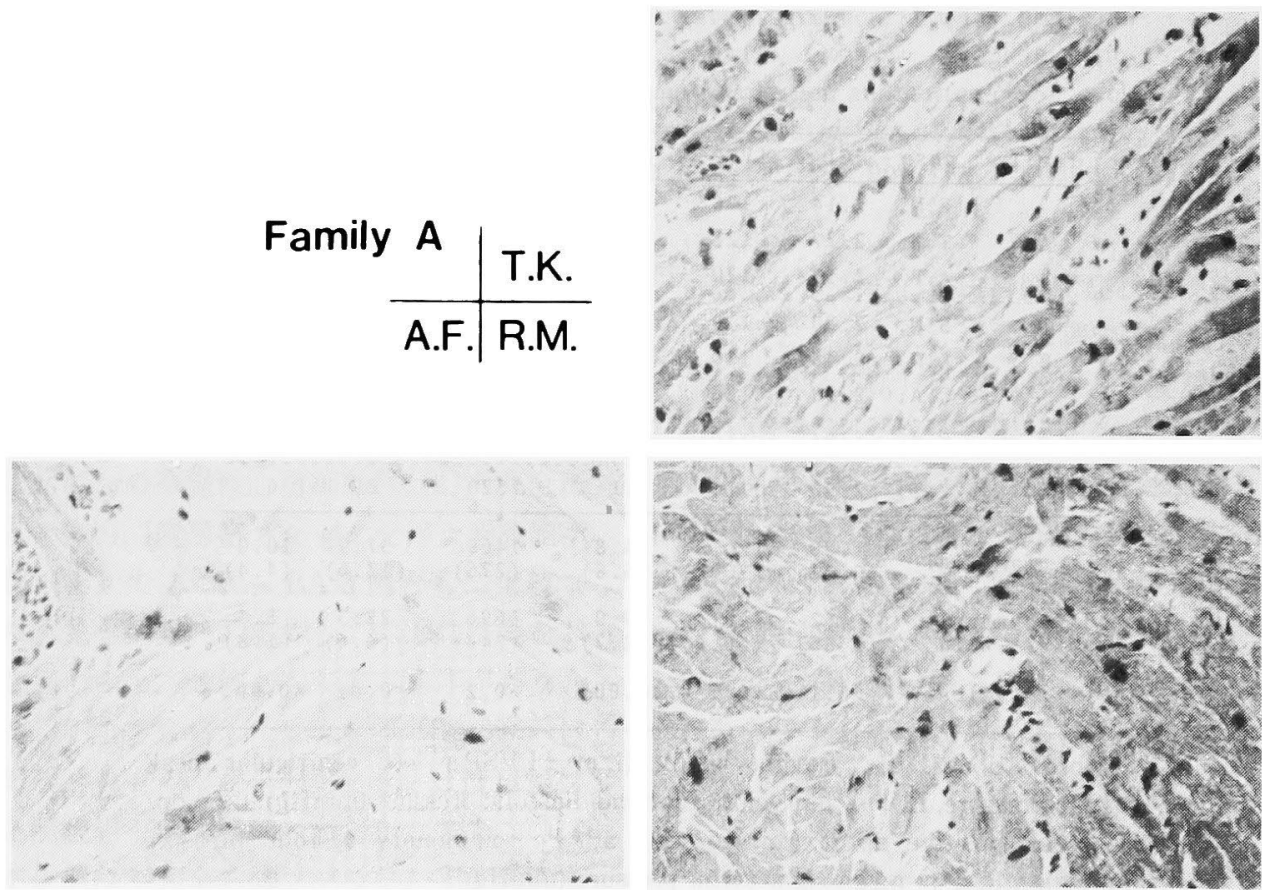

図 3、A 家系 3 例の右室心内膜心筋生検像（説明本文） 
表 4.8 例における心筋組織所見

\begin{tabular}{|c|c|c|c|c|c|}
\hline family & case & \multicolumn{4}{|c|}{ findings in RV-endomyocardial biopsy } \\
\hline \multirow{3}{*}{ A } & som & + & & & \\
\hline & i.n. & & & & \\
\hline & A. F. & ++ & t+ & ++ & \\
\hline \multirow{2}{*}{ B } & S.N. & + & ++ & ++ & \\
\hline & K.M. & & & & ++ \\
\hline \multirow[b]{2}{*}{$\mathrm{C}$} & M.S. & ++ & +++ & & +t+ \\
\hline & K.S. & & & & \\
\hline D & Y.T. & & & +++ & \\
\hline
\end{tabular}

表中のscoreは教室分類 ${ }^{13)}$ にる

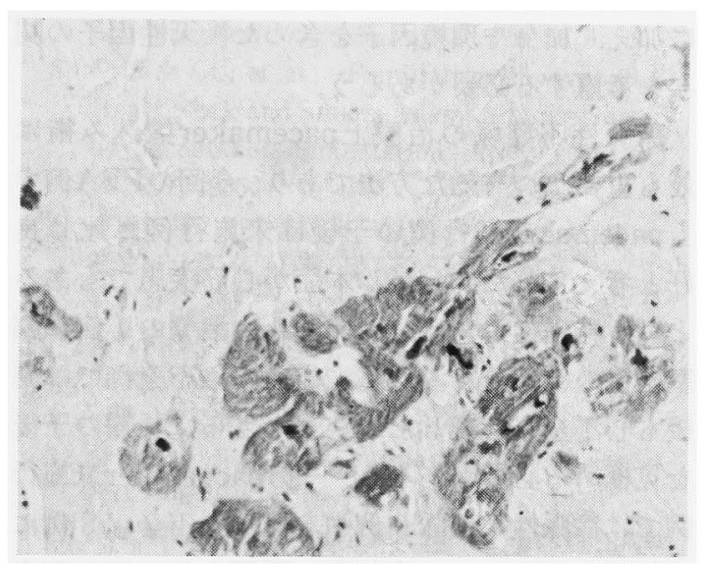

図 4.C家系KS例の左室心筋生検像

肥大が顕著であつた。なお今回の 8 例には炎症を 疑わせる細胞浸潤はなく、またamyloid沈着等も 認められなかつた。C家系の $\mathrm{KS}$ 例は他の例に比 し, 右室生検上著明な組織像を示さなかつたが, 心筋電極装着時の左室心筋生検では図 4 のごとく 著明な心筇变性と線維化像を認めた。

\section{4）臨床経過}

家系A中の 4 例, B中の 2 例，C中の 3 例，D中 の 1 例, 計10例にpacemaker治療 ( 9 例が右室心 内膜， 1 例が左室心筋電極）が施行された。10例 中 5 例は術前よりの心不全が術後も持続し， 2 例 が脳塞栓発生後の突然死および肺炎にて死亡し た. pacemaker未治療例はBA19例中 9 例で, 内明 らかな心不全を 6 例に認め，未治療の 9 例中 8 例 （89\%）が平均年令 42.1 才で突然死した。

\section{考 案}

成人型家族性不整脈の遺伝様式（主に常染色体
優性遺(伝 $\left.{ }^{810)}\right)$ や，その不整脈所見については既に いくつかの報告がある(1)-8). しかし，その臨床像， 血行動態所見, 病理組織学的所見に対する全般的 かつ詳細な検討は少なく 本症での興味ある問題 点の一つである特発性心筋症との関連性は, 未だ 不明と言わざるを得ない，本研究では家族性不整 脈のうち徐脈性不整脈を主徵とする 4 家系を検討 し，以下の結果を得た，1）家系内心電図検査を施 行した55例中，徐脈性不整脈は19例 (34.9\%) で あり,これらは脚ブロック, QRSの低電位差, poor R-wave progression, T波異常, VPCやVTを比較 的高頻度に合併した.2）19例中心不全合併が10例 で, 脳虚血発作のみは 3 例であつた，3）な扮本症 の不整脈発現や臨床病像の完成は30４0才台之考 えられた．4）心拡大・左室拡張が著明で，その心 機能は明らかに低下していた.5）8例でのほぼ共 通した病理組織所見として心筋の肥大, 变性, 錯 綜配列, 間質の線維化がみられた。 6）19例中10例 にpacemaker治療が施行され, 内 5 例では術後に も心不全が持続した。 未施行 9 例中 6 例に心不全 があり, 内 8 例が突然死した。

以上の結果とは逆に, 従来主に成人型の家族性 徐脈性不整脈, 特に房室ブロックでは，1）心不全 の合併は少なく2)，かつ心桩大は希である ${ }^{4)}$,2) 血 行力学的検査は正常で2), 3）心筋生検組織像に異 常がなく, 病理解剖所見についても刺激伝導系に 異常を認めるのみで, 心筋には異常を認めな (1) 3) また 4) 本症は特発性心筋症の所見を欠

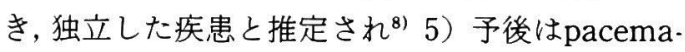
ker治療によつて良好8) と考劣られてきた. 今回の 症例はこれらの例に一致しないもので, その概要 は伝導系のみでなく, 固有心筋の障害のため, 心 機能はいわゆる“特発性徐脈性不整脈”に比して 著明に低下し，心不全を高率に合併すると言える。 本研究での対照群24例中全例が“特発性”ではな く，また全例が正常の心機能を有するものでもな く, 心不全合併例も数例含まれ ${ }^{12}$, これらを除外す ると対照群の諸指標はさらに良好となる事から FBAとの差はより明瞭となろう。

今回の症例の中には, 明らかな特発性拡張型心 
筇症 (idiopathic dilated cardiomyopathy, DCM) と推定される例（例党ばA家系のRM, HM, B家系 のSN, KN, C家系のKS例など)が存在する。交た 本症における脚ブロック，QRS低電位, poor Rwave progression, T波異常等の合併は，一般的に DCMの心電図所見之類似する ${ }^{11}$ 。一方，A家系の $\mathrm{AF}, \mathrm{C}$ 家系のMS，D家系のYT例のごと?，心形 態，心機能上特発性心筋症を示唆する所見がなく， 組織学的に心筋の錯綜配列を特改とした症例も含

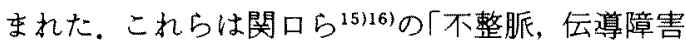
を主徵とする心筋症」に類似のものと言えよう。 ただし，注意すべきは長期徐脈下にある心臟の組 織学的変化であり, 当然心筋の肥大, 变性, さら には軽度の線維化等を合併する可能性があり ${ }^{17}$, これら所見のみでは特発性心筋症との鑑別は困難 となろう。しかし本研究の 8 例（表 4) は先述の ごとく DCMに類似する 5 例と AF, MS, YTの 3 例であり，いずれる著明な組織学的変化を伴い, また間質性慢性心筋炎乩ないし postmyocarditic change ${ }^{15)}$ の所見，あるいは虚血性病変1)考えに くく，現段階では特発性心筋症もしくはその類縁 疾患と考えたい。すなわら少なくともFBAの一部 例は伝導障害に加克, 固有心筋の障害も合併する と言党る。同様の報告はGriffith ${ }^{5)}$, 有田 ${ }^{6)}$, 外山ら ${ }^{7)}$ の例にもみられ，本症は特発性心筇症ないし家族 性心筋症と高率にoverlapする事から, 本症の全例 が“特発性心筋症の所見を欠く，独立した疾患 群”8)とは考奌にくい.

特発性心胆症が高率に家系内発現をみる事は周 知の事実である ${ }^{9110)}$ また本邦の集計では心筇症に 徐脈性不整脈（高度房室ブロックや洞機能不全症

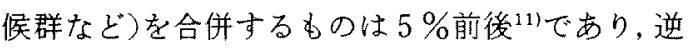
に高度房室ブロックの基礎疾患としての心筋疾患 に7.3\%の頻度でみられ ${ }^{18)}$, 著者らの徐脈例での心 筋疾患頻度も8.6\%(特発性のみでは $7 \%$ ) であ る(19) すなわち徐脈性不整脈の $5 \sim 7 \%$ の例は特

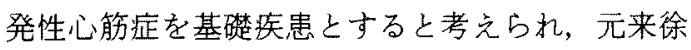
脈性不整脈々心筋症之は密接な関係にあると言克 る。特にDCM類似例において固有心筋の病変を中 心に考虑すれば，これら疾患群の成因を“心筋自
体の広範な障害に基づく心室内刺激伝導采障害に よる不整脈” 20)上も考光得上5。一方DCM様の所 見を示さず組織所見のみに異常を有した 3 例中, 錯綜配列の著明なYT例の成因を同様に考古得る か否かについてはさらに今後の検討を要しよう。

な㧍，病像の完成が30才ないし40才台にみられ， 20才未満例では伝導障害が軽微と考学られる事, 拉よび同一家系の同胞において心電図所見は注は 同一であつても，心機能障害の程度に差がみられ た事は，遺伝因子の浸透性の相違か，遺伝性素因 に加え，加令や環境因子を含めた後天性因子の関 与を考虑する必要があろら。

徐脈性不整脈の治療上 pacemaker植込及術は 最も重要かつ有効な方法であり, 今回のFBA例で b pacemaker施行例の予後は未施行例に比し良 好と考えられた。しかし本症が心筋疾患でもある といら特殊性のため, pacemaker治療の1例に脳 塞栓後の乫然死をみた事, 術前の心不全例では術 後も心不全が持続した事から，さらに長期の予啳 を見極める必要があろ5。一方pacemaker未施行 例では徐脈性不整脈 9 例中 6 例に心不全, 8 例に 突然死をみた。この突然死の原因としては心不全 招よび合併するVPC，VT等からの不整脈死，ある いは脳塞栓が推定される。従つて時期を失さぬ pacemaker治療，心不全や不整脈汶対する薬物治 療, 塞栓症予防のための抗凝固剂の併用は不可欠 であろう。その際生理的pacing modeの撰択，心 不全や不整脈の登重な監視, 凝固線溶系因子の測 定等の重要性については言らまでもない。

\section{まとめ}

成人型家族性徐脈性不整脈の 4 家系19例につい て，その心電図所見，臨床症状，血行動態拉よび 病理組織所見, 臨床経過を検討した。病像の完成 は30〜40才台と考えられ，心不全の合併率が高か つた、いわゆる特発性のものに比し，心機能は著 明に低下し，組織学的に心筋，間質の病的所見 を伴い，抬張型心筋症に類似する例もみれた。本 症は特発性心筋症々高率にoverlapし，必ずしも独 立した疾患とはみなし得ない，末治療例での予後 は突然死のために不良であるが, pacemaker治療 
は有効な方法といえる。

\section{文献}

1) Tsagaris $\mathrm{TJ}$, et al: Familial heart disease. Dis Chest $52: 153,1967$.

2) Lynch HT, et al: Hereditary progressive atrioventricular conduction defect. JAMA 225 : $1465,1973$.

3) Amat.Y.Leon F, et al: Familial atrial dysrhythmia with A.V block. Circulation 50 : 1097, 1974.

4) Waxman MB, et al: Familial atrioventricular heart block, An autosomal dominant trait. Circulation $51: 226,1975$.

5) Griffith GC, et al: Familial cardiomyopathy. Heart block and Stokes-Adams attacks treated by pacemaker implantation. Amer J Cardiol $16: 267,1965$.

6)有田真, 他：徐脈を主徵とし同胞に多発した心 筋症の一家采。心臹 $2: 59,1970$.

7）外山芳史，他：Sick Sinus Syndromeを主㟨とす 万特発性心荕症。Jap Circ J 40：110，1976.

8) 木村陽行，他：成人型家族性房室プックの家系。 心臓 8:936, 1976 .

9) Evans W: Familial cardiomegaly. Brit Heart J $11: 68,1949$.

10) Braunwald E, et al: Idiopathic hypertrophic subaortic stenosis: Description of the disease based upon an analysis of 64 patients. Circula. tion 30(Suppl IV): IV -3, 1964

11）河台忠一, 他：特発性心荕症の猃断基準について 厚生省特発性心筋症調查研究班（班長河合忠 一），昭和50年度報告集，1976，p88。

12）藤山增昭, 他：HR-COP関係の型別と心機能との 関連。心荿よーンン

13）戸嶋裕徳，他：肥大型心笳症の生㛟組織所見と心 電図所見との対比，厚生省特定矤患，特発性心筋 症調查研究班 (班長 戸鴆签徳)，昭和56年度研究 報告集, 1982, p 80。

14) Lynch HT, et al: Hereditary progressive atrioventricular conduction defect. Amer J Cardiol 36: 297, 1975.

15）関口守街，他：右心房心内膜心筋生换からみた Sick Sinus Syndromeの病態と心房心筋症の概念 について。心缄ベーシング，1980，p122。

16)岳マチ子：特発性心㬳症扰上び不整脈，层導障害 を主徵上する心㬳疾患の病因について，東女医大 誌 $52: 1417,1982$.

17) 足達 教, 他：Sick Sinus Syndromeの右心室心 内膜生検組織所見. 心橫ペーシング, 1982, p121.

18）畨場邦武，他：全国調查に上る高度房空プロック の予唩。儿䁍ヘーンンク，1977，p16。

19）戸嶋裕徳，他：ペースメーカー治療を施行した心 筋疾患の臨木的娭討。厚生省特定矢患特発性心筋 症調查研究班（班長 戸嶋裕徳），昭和54年度研究 報告書，1980，p184.

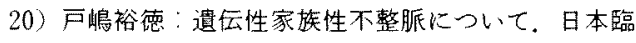
床 $32: 53,1974$. 